\title{
Impact of aerobic versus resisted exercise training on systemic inflammation biomarkers and quality of Life among obese post-menopausal women
}

\author{
Shehab M Abd El-Kader', Osama H Al-Jiffri ${ }^{2}$
}

\author{
1. Department of Physical Therapy, Faculty of Applied Medical Sciences, King Abdulaziz University, Jeddah, \\ Saudi Arabia. \\ 2. Department of Medical Laboratory Technology, Faculty of Applied Medical Sciences, King Abdulaziz \\ University, Jeddah, Saudi Arabia.
}

\begin{abstract}
Background: Although post-menopausal obesity is an important public national health problem in Saudi Arabia, to date no study has evaluated the effects of weight reduction on biochemical \& clinical parameters and quality of Life for obese Saudi post-menopausal women.

Objective: The aim of this study was examine the effects of aerobic versus resisted exercise training effects upon systemic inflammation biomarkers and quality of life for obese post-menopausal Saudi women.

Material and Methods: One hundred Saudi post-menopausal obese women participated in this study, their age ranged from 50-58 years and their body mass index (BMI) ranged from $30-35 \mathrm{~kg} / \mathrm{m} 2$. All participants were divided into two equal groups: The first group received aerobic exercise training on treadmill where, the second group received resisted exercise training. Health-related quality of life (SF-36 HRQL), tumor necrosis factor-alpha(TNF- $\alpha$ ), Interleukin-2(IL-2), Interleukin-4 (IL-4), Interleukin-6 (IL-6) and C-reactive protein (CRP) were measured before and after 3 months at the end of the study.

Results: The mean values of SF-36 HRQL subscale scores were significantly increased, while the mean value of TNF- $\alpha$, Il2, IL-4, IL-6,CRP and BMI were significantly decreased in both groups after treatments. There were significant differences between mean levels of the investigated parameters in group (A) and group (B) after treatment with more changes in patients received aerobic exercise training.

Conclusion: The current study provides evidence that aerobic exercise is more appropriate than resisted exercise training in modulating inflammatory cytokines and quality of life among obese post-menopausal women.

Keywords: Aerobic exercise; resisted exercises; inflammatory cytokine; quality of life; obesity; menopause.

DOI: https://dx.doi.org/10.4314/ahs.v19i4.10

Cite as: Abd El-Kader SM, Al-Jiffri OH. mpact of aerobic versus resisted exercise training on systemic inflammation biomarkers and quality of Life among obese post-menopausal women. Afri Health Sci. 2019;19(4):2881-2891. bttps:// dx.doi.org/10.4314/abs.v19i4.10
\end{abstract}

\section{Introduction}

Post-menopausal women, especially those with body mass index (BMI) greater than $30 \mathrm{~kg} / \mathrm{m} 2$, have lower health-related quality of life (HRQOL) in physical functioning, energy, and vitality compared with normal-weight women ${ }^{1}$. Nearly two-thirds of American adults are overweight or obese $^{2}$. The current epidemic of overweight and obesity
Corresponding author:
Shehab M Abd El-Kader,
Department of Physical Therapy,
Faculty of Applied Medical Sciences,
King Abdulaziz University,
P.O. Box 80324, Jeddah, 21589, Saudi Arabia.
Email: salmuzain@kau.edu.sa

is one of the major public health concerns worldwide ${ }^{3}$. The prevalence of overweight and obesity has increased significantly over the past 30 years, with overweight and obesity now affecting 1.5 billion adults globally ${ }^{4}$. Worldwide, 2.8 million people die each year of obesity-related diseases, including type 2 diabetes mellitus (T2DM), cardiovascular disease (CVD), and metabolic syndrome ${ }^{5}$.

Obesity may significantly reduce HRQOL. A review of 8 studies examining HROQL among women aged over 55 years old concluded that post-menopausal women, especially those with BMI greater than $30 \mathrm{~kg} / \mathrm{m} 2$, have lower HRQOL in physical functioning, energy, and vitality compared with normal-weight women1. Obesity impacts a variety of dimensions of quality of life, including vitality, bodily pain, and even social functioning. Obese individuals report significantly lower HRQL than nor-

(C) 2019 Abd El-Kader et al. Licensee African Health Sciences. This is an Open Access article distributed under the terms of the Creative commons Attribution License (https://creativecommons.org/licenses/BY/4.0), which permits unrestricted use, distribution, and reproduction in any medium, provided the original work is properly cited. 
mal-weight individuals ${ }^{6}$. General health problems, mobility/functional disability, depression and low self-esteem are commonly reported among obese subjects ${ }^{7}$.

Quality of life (QoL) in post-menopausal women may be compromised as a consequence of climacteric symptoms associated to psychosocial and cultural determinants ${ }^{8}$. There is a growing demand for health care proposals aimed at menopausal women and looking to promote a healthier female aging process and with a better QoL? Hormone replacement therapy (HRT) has been indicated to minimize menopausal symptoms; however there are controversies as to whether its effects improve QoL. There are still some questions regarding the risks and benefits of HRT in post-menopausal women ${ }^{10,11}$.

Aerobic exercise training is an effective and cost-efficient alternative therapy for disorders of anxiety and mood disorders $^{12}$. Also, exercise training slow down the progression of cognitive decline ${ }^{13}$, improves performance on tests of cognition and psychological wellbeing ${ }^{14}$ and enhances sleep quality ${ }^{15}$. However, the available previous studies involving the impact of exercise training upon the quality of life, psychological wellbeing along with systemic inflammation in post-menopausal women is limited in number ${ }^{16}$.
As the ideal exercise intensity that efficiently modulates the elevated inflammatory cytokines and abnormal HRQOL among obese post-menopausal women is inconclusive, this study was designed to compare the impact of aerobic versus resisted exercises on inflammatory cytokines and HRQOL in obese post-menopausal women.

\section{Patients and methods \\ Subjects}

One-hundred Saudi post-menopausal obese women participated in this study, their age ranged from 50-58 years and their BMI ranged from $30-35 \mathrm{~kg} / \mathrm{m} 2$. All volunteers were asked to read and sign an informed consent document prior to participation. Women who were smokers, having any endocrine, musculoskeletal, renal, liver, cardiac disorders, diabetes and chest diseases were excluded. Participants were assigned into 2 groups; group (A) received aerobic exercise training for 3 months and group (B) received resisted exercise training. The CONSORT diagram outlining the details of the screening, run-in and randomization phases of the study and reasons for participant exclusion can be found in figure (1). Informed consent was obtained from all participants. This study was approved by the Scientific Research Ethical Committee, Faculty of Applied Medical Sciences at King University.

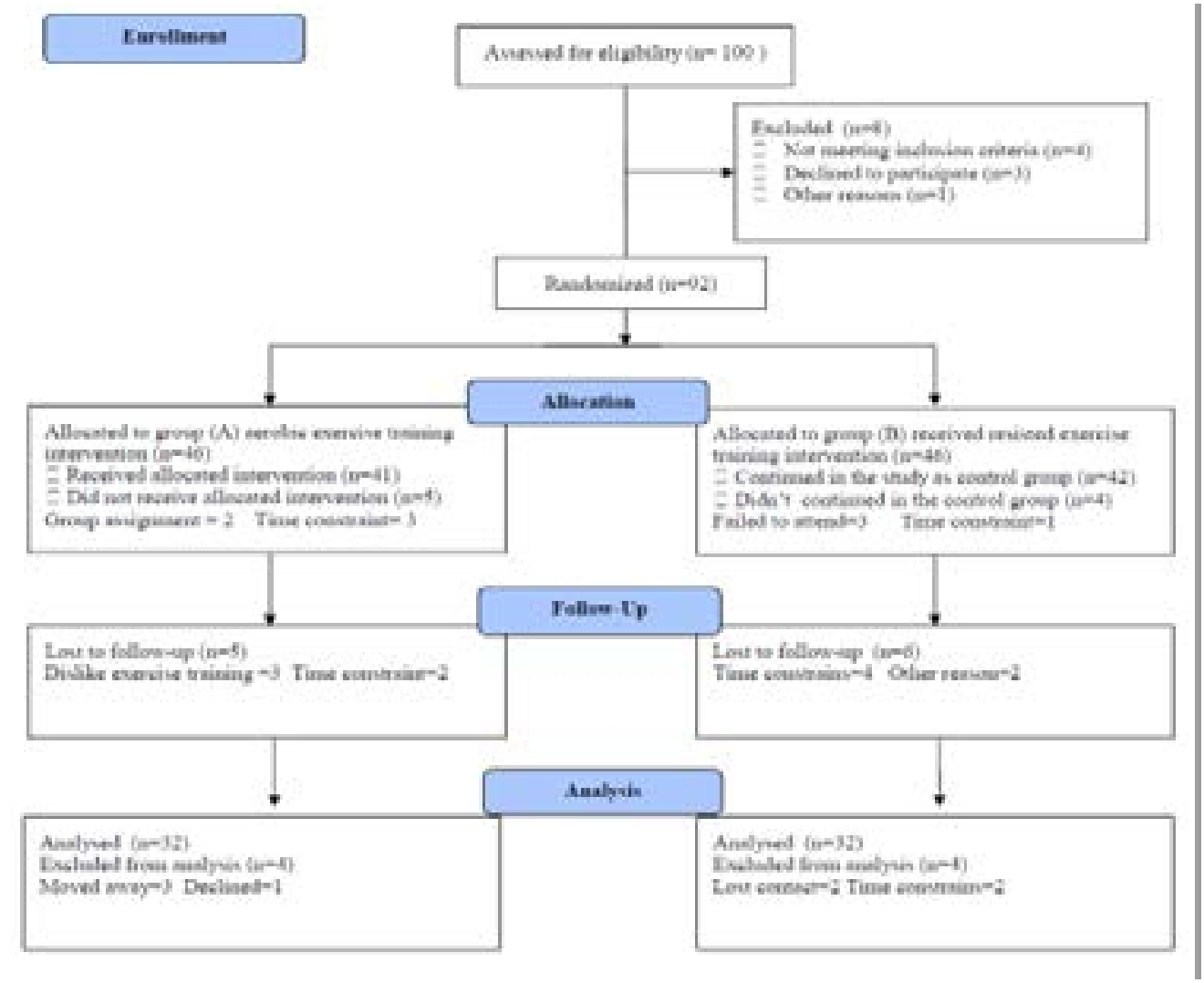

Figure (1): Subjects screening and recruitment CONSORT diagram. 


\section{Measurements}

1. Health-related quality of life (SF-36 HRQL): The SF-36 included eight subscales: Vitality, Bodily Pain, General Health, Physical Functioning, Social Functioning, Physical Role Functioning, Emotional Role Functioning, and Mental Health. In addition to these subscales, the SF36 also included a question asking participants to report the amount of change in their general health over the past year referred to as health transition ${ }^{17}$.

2. Biochemical analyses: Blood samples were drained from the antecubital vein after a 12 -h fasting, the blood samples were centrifuged at $+4{ }^{\circ} \mathrm{C}(1000=\mathrm{g}$ for $10 \mathrm{~min})$. Interleukin-2 (IL-2) Interleukin-4 (IL-4), Interleukin-6 (IL-6) levels were analyzed by “Immulite 2000” immunassay analyzer (Siemens Healthcare Diagnostics, Deerfield, USA). However, tumor necrosis factor- alpha (TNF- $\alpha$ ) and C-reactive protein (CRP) levels were measured by ELISA kits (ELX 50) in addition to ELISA microplate reader (ELX 808; BioTek Instruments, USA). Measurements of TNF- $\alpha$, Il-2, IL-4, IL- 6 and CRP were taken before starting of the study (pre-test) and after 12 weeks (post-test).

All measurements were taken before the starting of the study (pre-test) and after three months at the end of the study (post-test).

\section{Procedures}

Following the previous evaluation, all participants were assigned into two groups:

1. Group (A) participated in a treadmill aerobic exercise (Enraf Nonium, Model display panel Standard,
NR 1475.801, Holand) which was conducted according to recommendation of aerobic exercise application approved by the American College of Sports Medicine ${ }^{18}$. Training program was included five minutes for warming -up in the form of range motion and stretching exercises , thirty minutes of aerobic exercise training ( $60-70 \%$ of maximum heart rate) and five minutes of cooling down (on treadmill with low speed and without inclination). Participants had three sessions / week for 3 months with close supervision of physical therapist.

2. Group (B) participated in the resistance exercises on some resistance gym machines (Nautilus Sports/Medical Industries, Independence, VA), three sessions of resistance exercise training / week for 3 months. Each session of resistance training program included five minutes for warming -up in the form of range motion and stretching exercises, 30 minutes of resistance exercise training and 5 minutes of cooling down ${ }^{19}$.

\section{Statistical analysis}

The mean values of the investigated parameters obtained before and after three months in both groups were compared using paired " $t$ " test. Independent " $t$ " test was used for the comparison between the two groups $(\mathrm{P}<0.05)$.

\section{Results}

Table 1 shows the baseline characteristics of the participants who entered the trial. There was no significant differences in baseline characteristics between the two groups were found.

Table 1: Baseline characteristics of study participants.

\begin{tabular}{|l|l|l|l|}
\hline Characteristic & Group (A) & Group (B) & Significance \\
\hline Age $($ years) & $56.42 \pm 4.81$ & $54.97 \pm 5.63$ & $\mathrm{P}>0.05$ \\
\hline BMI $\left(\mathrm{kg} / \mathrm{m}^{2}\right)$ & $34.28 \pm 3.74$ & $33.52 \pm 3.68$ & $\mathrm{P}>0.05$ \\
\hline SBP $(\mathrm{mmHg})$ & $136.51 \pm 11.46$ & $135.14 \pm 13.12$ & $\mathrm{P}>0.05$ \\
\hline DBP $(\mathrm{mmHg})$ & $82.33 \pm 6.27$ & $80.81 \pm 7.52$ & $\mathrm{P}>0.05$ \\
\hline Glucose (mmol/L) & $4.51 \pm 0.64$ & $4.35 \pm 0.53$ & $\mathrm{P}>0.05$ \\
\hline ALT $(\mathrm{U} / \mathrm{L})$ & $40.16 \pm 7.23$ & $38.62 \pm 6.11$ & $\mathrm{P}>0.05$ \\
\hline AST (U/L) & $28.45 \pm 6.18$ & $27.71 \pm 5.39$ & $\mathrm{P}>0.05$ \\
\hline
\end{tabular}

BMI: Body mass index; ALT: Alanine aminotransferase; AST: Aspartate aminotransferase; SBP: Systolic blood pressure; DBP: Diastolic blood pressure. 
The mean values of SF-36 HRQL subscale scores and 6MW'T were significantly increased, while the mean value of TNF- $\alpha$, Il-2, IL-4, IL-6, CRP and BMI were significantly decreased in both groups after treatments (Tables 2-5). There were significant differences between mean levels of the investigated parameters of group (A) and group (B) after treatment with more changes in patients received aerobic exercise training (Tables 6 and 7). These results confirm that aerobic exercise is more appropriate than resisted exercise training in modulating inflammatory cytokines and quality of life among obese post-menopausal women.

Table 2: Mean value and significance of TNF- $\alpha$, IL-2, IL-4, IL-6 and CRP of group (A) before and at the end of the study.

\begin{tabular}{|c|c|c|c|c|}
\hline & \multicolumn{2}{|c|}{ Mean +SD } & \multirow[t]{2}{*}{ T-value } & \multirow[t]{2}{*}{ Significance } \\
\hline & Before & After & & \\
\hline TNF- $\boldsymbol{\alpha}(\mathrm{pg} / \mathrm{ml})$ & $\begin{array}{l}6.36 \pm \\
1.74^{*}\end{array}$ & $4.38 \pm 1.86$ & 7.11 & $\mathrm{P}<0.05$ \\
\hline IL-2 (pg/ml) & $\begin{array}{l}8.23 \pm \\
2.31 *\end{array}$ & $4.75 \pm 1.97$ & 6.58 & $\mathrm{P}<0.05$ \\
\hline IL-4(pg/ml) & $\begin{array}{l}5.72 \pm \\
1.44^{*}\end{array}$ & $3.46 \pm 1.23$ & 6.25 & $\mathrm{P}<0.05$ \\
\hline IL-6 (pg/ml) & $\begin{array}{l}7.85 \pm \\
2.13^{*} \\
\end{array}$ & $4.55 \pm 1.81$ & 6.22 & $\mathrm{P}<0.05$ \\
\hline $\mathbf{C R P}(\mathrm{mg} / \mathrm{dl})$ & $\begin{array}{l}14.93 \pm \\
3.82 *\end{array}$ & $8.31 \pm 2.75$ & 8.43 & $\mathrm{P}<0.05$ \\
\hline
\end{tabular}

TNF- $\alpha$ : tumor necrosis factor - alpha; IL-2: Interleukin-2; IL-4: Interleukin-4; IL-6: Interleukin-6; CRP: C-reactive protein, $(*)$ indicates a significant difference between the two groups, $\mathrm{P}<0.05$.

Table 3: Mean value and significance of SF-36 subscale scores of group (A) before and at the end of the study.

\begin{tabular}{|c|c|c|c|c|}
\hline \multirow{2}{*}{$\begin{array}{l}\text { SF-36 subscale } \\
\text { variables }\end{array}$} & \multicolumn{2}{|l|}{ Mean + SD } & \multirow[t]{2}{*}{ T-value } & \multirow[t]{2}{*}{ Significance } \\
\hline & Before & After & & \\
\hline $\begin{array}{l}\text { SF-36: Health } \\
\text { transition }\end{array}$ & $2.75 \pm 0.83^{*}$ & $1.69 \pm 0.61$ & 5.34 & $\mathrm{P}<0.05$ \\
\hline $\begin{array}{l}\text { SF-36: Physical } \\
\text { functioning }\end{array}$ & $\begin{array}{ll}72.18 & \pm \\
9.43 * & \end{array}$ & $80.32 \pm 10.12$ & 6.76 & $\mathrm{P}<0.05$ \\
\hline $\begin{array}{l}\text { SF-36: } \\
\text { functioning: } \\
\text { Physical }\end{array}$ & $\begin{array}{l}78.96 \\
10.15 *\end{array}$ & $87.13 \pm 12.37$ & 6.81 & $\mathrm{P}<0.05$ \\
\hline SF-36: Bodily pain & $\begin{array}{l}75.11 \\
7.63 *\end{array}$ & $69.85 \pm 6.25$ & 6.52 & $\mathrm{P}<0.05$ \\
\hline $\begin{array}{ll}\text { SF-36: } & \text { General } \\
\text { health } & \end{array}$ & $\begin{array}{l}71.16 \\
9.44 *\end{array}$ & $77.38 \pm 10.19$ & 7.35 & $\mathrm{P}<0.05$ \\
\hline SF-36: Vitality & $\begin{array}{l}57.27 \\
6.32 *\end{array}$ & $66.97 \pm 7.81$ & 6.41 & $\mathrm{P}<0.05$ \\
\hline $\begin{array}{ll}\text { SF-36: } & \text { Social } \\
\text { functioning } & \end{array}$ & $\begin{array}{l}85.18 \\
11.17 *\end{array}$ & $92.26 \pm 13.31$ & 8.15 & $\mathrm{P}<0.05$ \\
\hline $\begin{array}{l}\text { SF-36: } \\
\text { functioning: } \\
\text { Emotional }\end{array}$ & $\begin{array}{l}92.42 \\
15.26^{*}\end{array}$ & $84.51 \pm 14.13$ & 7.86 & $\mathrm{P}<0.05$ \\
\hline $\begin{array}{ll}\text { SF-36: } & \text { Mental } \\
\text { health } & \end{array}$ & $\begin{array}{l}84.71 \\
10.14 *\end{array}$ & $78.24+8.97$ & 6.91 & $\mathrm{P}<0.05$ \\
\hline
\end{tabular}

(*) indicates a significant difference between the two groups; $\mathrm{P}<0.05$. 
Table 4: Mean value and significance of TNF- $\alpha$, IL-6, IL-8 and CRP of group (B) before and after treatment.

\begin{tabular}{|l|l|l|l|l|}
\hline & \multicolumn{2}{|l|}{ Mean +SD } & \multirow{2}{*}{ T- value } & Significance \\
\cline { 2 - 4 } & Before & After & \\
\hline TNF- $\boldsymbol{\alpha}(\mathrm{pg} / \mathrm{ml})$ & $5.93 \pm 1.82^{*}$ & $5.13 \pm 1.78$ & 3.61 & $\mathrm{P}<0.05$ \\
\hline IL-2 $(\mathrm{pg} / \mathrm{ml})$ & $8.15 \pm 2.49^{*}$ & $6.74 \pm 2.21$ & 3.87 & $\mathrm{P}<0.05$ \\
\hline IL-4 $(\mathrm{pg} / \mathrm{ml})$ & $5.63 \pm 1.61^{*}$ & $4.37 \pm 1.54$ & 3.52 & $\mathrm{P}<0.05$ \\
\hline IL-6 $(\mathrm{pg} / \mathrm{ml})$ & $7.65 \pm 2.38^{*}$ & $6.14 \pm 2.25$ & 3.68 & $\mathrm{P}<0.05$ \\
\hline CRP $(\mathrm{mg} / \mathrm{dl})$ & $\begin{array}{l}14.67 \pm \\
3.91 *\end{array}$ & $11.82 \pm 3.27$ & 4.36 & $\mathrm{P}<0.05$ \\
\hline
\end{tabular}

TNF- $\alpha$ : tumor necrosis factor - alpha; IL-2: Interleukin-2; IL-4: Interleukin-4; IL-6: Interleukin-6; CRP: C-reactive protein, $(*)$ indicates a significant difference between the two groups, $\mathrm{P}<0.05$.

Table 5: Mean value and significance of SF-36 subscale scores of group (B) before and at the end of the study.

\begin{tabular}{|l|l|l|l|l|}
\hline \multirow{2}{*}{$\begin{array}{l}\text { SF-36 subscale } \\
\text { variables }\end{array}$} & Mean \pm SD & T- value & Significance \\
\cline { 2 - 5 } $\begin{array}{l}\text { SF-36: Health } \\
\text { transition }\end{array}$ & $2.61 \pm 0.92^{*}$ & $2.11 \pm 0.84$ & 3.19 & $\mathrm{P}<0.05$ \\
\hline $\begin{array}{l}\text { SF-36: Physical } \\
\text { functioning }\end{array}$ & $73.27 \pm 8.51^{*}$ & $77.68 \pm 8.96$ & 3.23 & $\mathrm{P}<0.05$ \\
\hline $\begin{array}{l}\text { SF-36: Role } \\
\text { functioning: } \\
\text { Physical }\end{array}$ & $80.21 \pm 10.39^{*}$ & $84.34 \pm 10.75$ & 3.42 & $\mathrm{P}<0.05$ \\
\hline SF-36: Bodily pain & $73.92 \pm 7.48^{*}$ & $70.74 \pm 7.23$ & 3.22 & $\mathrm{P}<0.05$ \\
\hline $\begin{array}{l}\text { SF-36: General } \\
\text { health }\end{array}$ & $72.15 \pm 9.87^{*}$ & $75.22 \pm 10.12$ & 3.15 & $\mathrm{P}<0.05$ \\
\hline SF-36: Vitality & $57.81 \pm 6.42^{*}$ & $62.13 \pm 6.76$ & 3.41 & $\mathrm{P}<0.05$ \\
\hline $\begin{array}{l}\text { SF-36: Social } \\
\text { functioning }\end{array}$ & $86.24 \pm 11.26^{*}$ & $89.57 \pm 11.87$ & 3.27 & $\mathrm{P}<0.05$ \\
\hline $\begin{array}{l}\text { SF-36: Role } \\
\text { functioning: } \\
\text { Emotional }\end{array}$ & $90.83 \pm 14.91^{*}$ & $87.14 \pm 13.22$ & 3.31 & $\mathrm{P}<0.05$ \\
\hline $\begin{array}{l}\text { SF-36: Mental } \\
\text { health }\end{array}$ & $84.16 \pm 10.38^{*}$ & $81.25 \pm 10.18$ & 3.45 & $\mathrm{P}<0.05$ \\
\hline
\end{tabular}

$(*)$ indicates a significant difference between the two groups; $\mathrm{P}<0.05$. 
Table 6: Mean value and significance of TNF- $\alpha$, IL-6, IL-8 and CRP of group (A) and group (B) at the end of the study.

\begin{tabular}{|l|l|l|l|l|}
\hline & \multicolumn{2}{|l|}{ Mean +SD } & T- value & Significance \\
\cline { 2 - 3 } & Group (A) & Group (B) & & \\
\hline TNF- $\boldsymbol{\alpha}(\mathrm{pg} / \mathrm{ml})$ & $4.38 \pm 1.86^{*}$ & $5.13 \pm 1.78$ & 3.41 & $\mathrm{P}<0.05$ \\
\hline IL-2 $(\mathrm{pg} / \mathrm{ml})$ & $4.75 \pm 1.97^{*}$ & $6.74 \pm 2.21$ & 3.53 & $\mathrm{P}<0.05$ \\
\hline IL-4 $(\mathrm{pg} / \mathrm{ml})$ & $3.46 \pm 1.23^{*}$ & $4.37 \pm 1.54$ & 3.68 & $\mathrm{P}<0.05$ \\
\hline IL-6 $(\mathrm{pg} / \mathrm{ml})$ & $4.55 \pm 1.81^{*}$ & $6.14 \pm 2.25$ & 3.47 & $\mathrm{P}<0.05$ \\
\hline CRP $(\mathrm{mg} / \mathrm{dl})$ & $8.31 \pm 2.75^{*}$ & $11.82 \pm 3.27$ & 4.15 & $\mathrm{P}<0.05$ \\
\hline
\end{tabular}

TNF- $\alpha$ : tumor necrosis factor - alpha; IL-2: Interleukin-2; IL-4: Interleukin-4; IL-6: Interleukin-6; CRP: C-reactive protein, $(*)$ indicates a significant difference between the two groups, $\mathrm{P}<0.05$.

Table 7: Mean value and significance of SF-36 subscale scores of group (A) and group (B) at the end of the study.

\begin{tabular}{|l|l|l|l|l|}
\hline \multirow{2}{*}{$\begin{array}{l}\text { SF-36 subscale } \\
\text { variables }\end{array}$} & \multicolumn{2}{|l|}{ Mean \pm T- value } & Significance \\
\cline { 2 - 3 } $\begin{array}{l}\text { SF-36: Health } \\
\text { transition }\end{array}$ & $1.69 \pm 0.61^{*}$ & $2.11 \pm 0.84$ & 3.27 & $\mathrm{P}<0.05$ \\
\hline $\begin{array}{l}\text { SF-36: Physical } \\
\text { functioning }\end{array}$ & $80.32 \pm 10.12^{*}$ & $77.68 \pm 8.96$ & 3.46 & $\mathrm{P}<0.05$ \\
\hline $\begin{array}{l}\text { SF-36: Role } \\
\text { functioning: } \\
\text { Physical }\end{array}$ & $87.13 \pm 12.37^{*}$ & $84.34 \pm 10.75$ & 3.49 & $\mathrm{P}<0.05$ \\
\hline $\begin{array}{l}\text { SF-36: Bodily } \\
\text { pain }\end{array}$ & $69.85 \pm 6.25^{*}$ & $70.74 \pm 7.23$ & 3.35 & $\mathrm{P}<0.05$ \\
\hline $\begin{array}{l}\text { SF-36: General } \\
\text { health }\end{array}$ & $77.38 \pm 10.19^{*}$ & $75.22 \pm 10.12$ & 3.18 & $\mathrm{P}<0.05$ \\
\hline SF-36: Vitality & $66.97 \pm 7.81^{*}$ & $62.13 \pm 6.76$ & 3.52 & $\mathrm{P}<0.05$ \\
\hline $\begin{array}{l}\text { SF-36: Social } \\
\text { functioning }\end{array}$ & $92.26 \pm 13.31^{*}$ & $89.57 \pm 11.87$ & 3.32 & $\mathrm{P}<0.05$ \\
\hline $\begin{array}{l}\text { SF-36: Role } \\
\text { functioning: } \\
\text { Emotional }\end{array}$ & $84.51 \pm 14.13^{*}$ & $87.14 \pm 13.22$ & 3.61 & $\mathrm{P}<0.05$ \\
\hline $\begin{array}{l}\text { SF-36: Mental } \\
\text { health }\end{array}$ & $78.24+8.97 *$ & $81.25 \pm 10.18$ & 3.54 & $\mathrm{P}<0.05$ \\
\hline
\end{tabular}

$(*)$ indicates a significant difference between the two groups; $\mathrm{P}<0.05$.

\section{Discussion}

Regular physical activity may attenuate post-menopausal symptoms related to physical and behavioral changes, positively influencing QOL ${ }^{9,11,20}$. However, studies on the effects of aerobic exercises alone are found in literature $^{11,21}$. The fact that resisted exercise enhances muscle strength $^{22}$ and body composition ${ }^{23}$ is well established, but the association of resisted exercise to QOL improvement has not been demonstrated. Therefore, the aim of this study was to examine the effects of aerobic versus resisted exercise training effects upon systemic inflammation biomarkers and quality of life among sedentary obese post-menopausal women. 
The results of our study regarding the QOL proved that both aerobic and resisted exercise training group improved mean values of SF-36 subscale scores in obese post-menopausal women. In addition, there was a significant difference between both groups at the end of the study with more reduction of group (A) received aerobic exercise training. Our findings were consistent with several studies have shown that exercise intervention might enhance health-related quality of life and psychological well-being ${ }^{24-31}$ as Teomana et al. enrolled 81 volunteer post-menopausal women who have been taking hormone replacement treatment (HRT) were divided randomly into two groups: exercise group (which wasomposed of sub-maximal aerobic exercises for a 6 -week period 3 times a week) and control group (received no training intervention). At the end of 6 weeks exercise period, they found statistically significant differences in quality of life, strength, endurance, flexibility and balance parameters in the exercise group ${ }^{24}$. However, Kanemaru et al. randomly assigned sixty-three osteoporotic women over 60 years to 12 months of muscle exercise or to no intervention, they proved that QOL, grip strength and maximum walking speed increased significantly in the intervention group, while there were no improvements in any of the parameters in the control group ${ }^{25}$.

While, de Souza Santos et al. conducted a longitudinal study that was quasi-experimental and correlational on 323 post-menopausal elderly women who practiced dancing or walking over a 10 -month period, their results demonstrated significant differences for the post-test assessment of functional capacity $(5.63 \%)$ and general QoL $(9.19 \%)^{26}$. In addition, Berin et al. conducted a randomized controlled study on sixty symptomatic and sedentary post-menopausal women with a mean of at least four moderate to severe hot flushes per day or 28 per week will be randomized to an exercise intervention or unchanged physical activity (control group). The intervention consists of 15 weeks of standardized resistance training performed three times a week under supervision of a physiotherapist. They proved that exercise training is an effective treatment for hot flushes among post-menopausal women ${ }^{27}$. Moreover, Küçükçakır et al. enrolled seventy women with the diagnosis of post-menopausal osteoporosis in a supervised Pilates exercise program twice a week for one year, they concluded that Pilates exercises may be a safe and an effective treatment alternative for the quality of life in patients with post-menopausal osteoporosis $^{28}$. In the other hand, Sattar et al. investigated the impact of aquatic-resistance training on Quality of life in twenty four post-menopausal women. The aquatic-resistance training was administered for a period of 8 weeks, 3 days a week; a session each day. Their results revealed aquatic-resistance training produced positive impacts on the quality of life in post-menopausal women ${ }^{29}$. Also, Bonganha et al. assessed the body composition, muscle strength and qualty of life (QoL) changes following 16 weeks of resistance training in 32 healthy, non-active women who were not under hormone replacement therapy (HRT), classified as control group (CG, $n=16$ ) and training group ( $T G, n=16)$, they concluded that the 16-week program of RT was not enough to influence the perception of QoL in post-menopausal women ${ }^{30}$. While, Imayama et al. conducted a study one Middle-aged women $(n=100)$ and men $(n=102)$ were randomly assigned to either exercise $(360 \mathrm{~min} /$ week of moderate-to-vigorous aerobic exercise) or control and HRQOL (SF-36) were assessed at baseline and 12 months and proved that this level of exercise may increase HRQOL among overweight women ${ }^{31}$.

Although the exact mechanism for the effect of exercises on mental health is still unknown, several physiological and psychological mechanisms have been proposed, including increased feelings of self-efficacy, self-perceptions of control, reduced emotional strain and physiological responses to stress, and beneficial effects on neurotransmitters ${ }^{32}$. In addition, physical activity appears to stimulate neurogenesis ${ }^{33}$, enhance neuronal survival ${ }^{34}$ and increase synaptic plasticity ${ }^{35}$. Exercise promotes brain vascularization $^{36,37}$. Social contact may be an important mechanism, and subjects who take regular exercise may, as a result, get positive feedback from other people and an increased sense of self-worth ${ }^{38}$.

In our study, the mean values of TNF- $\alpha$, IL-2, IL-4, IL-6 and CRP were significantly decreased in both groups. In addition, there was a significant difference between both groups at the end of the study with more reduction of group (A) received aerobic exercise training. This means that in obese post-menopausal women aerobic exercise is more appropriate for modulating inflammatory cytokine levels than is resisted exercise training. These results are in line with many previous studies ${ }^{39-50}$ as Dekker et al. stated that a 12 -week exercise intervention resulted in a significant decrease in circulating IL-6 in subjects with 
type 2 diabetes mellitus who underwent an exercise program without weight loss ${ }^{39}$. In addition, there is evidence of lowered IL- 6 and TNF- $\alpha$ after prolonged exercise in obese women ${ }^{40}$ and decreased TNF- $\alpha$ after 12 weeks of aerobic exercise in patients with heart disease ${ }^{41}$. Moreover, in obese post-menopausal women with type 2 diabetes, 14 weeks of aerobic exercise decreased CRP by $15 \%$ and marginally decreased IL-6 $(p=0.07)^{42}$. Likewise, 12 week of exercise reduced IL-18 levels by $17.5 \%$ in patients with metabolic syndrome ${ }^{43}$. On the other side, Rosety-Rodriguez and colleagues in their study on 24 young male adults with Down syndrome who were assigned to perform resistance circuit training with 6 stations, 3 days per week for 12 weeks. They proved that Resistance circuit training improved low-grade systemic inflammation ${ }^{44}$. In addition, Brooks et al. stated that a 16-week resistance training intervention reduced CRP and increased adiponectin levels in older adults with type 2 diabetes ${ }^{45}$. While, Neto et al. proved that high-intensity exercise training program induced an anti-inflammatory effect (a reduction of IL-6, TNF- $\alpha$ \& leptin and an increase of IL- $4 \&$ IL-10 $)^{46}$. In contrast to the previous studies Rall et al. reported that 12 week of high-intensity progressive resistance strength training does not affect TNF $\alpha$, IL-6, or IL- $2^{47}$.

Also, Rodrigo and colleagues founded that weight-lifting exercises for 6 muscle groups in the upper and lower limbs ( 2 sets of 8 repetitions each), and the initial load was set at $80 \%$ of the 1 -repetition maximum load for one month led to improvement in the six minute walking test, health related quality of life (HRQOL) and lower-limb muscle strength, without altering the levels of systemic inflammation ${ }^{48}$. Also, Nikseresht et al. conducted a 12 week study on middle-aged obese men and proved that aerobic interval training consisted of running on a treadmill (4 sets of 4 minutes at $80-90 \%$ of maximal heart rate, with 3 -minute recovery intervals) had better anti-inflammatory effects (as indicated by the IL-10: TNF- $\alpha$ ratio) than nonlinear resistance training consisted of 40-65 minutes of weight training at different intensities with flexible periodization ${ }^{49}$. While, Kohut et al. proved that aerobic exercise intervention, but not flexibility/resistance exercise, reduces serum inflammatory cytokines including interleukin-18 (IL-18), CRP and IL-6 among older adults; this reduction would be mediated, in part, by improvements in psychosocial factors and/or by $\beta$-adrenergic receptor mechanisms ${ }^{50}$.
The exact mechanisms by which physical activity may reduce inflammation are not entirely understood, there are some data pointing to factors that may contribute to an effect of repeated bouts of muscle contraction leading to improvements in inflammatory status over time as exercise training-induced improvements in inflammatory status may also result from the modulation of intracellular signaling pathways and cellular function that are mediated by nitric oxide (NO) and $\mathrm{ROS}^{51}$. Moreover, the potential mechanisms for the anti-inflammatory effect of exercise may include reduced percentage of body fat and macrophage accumulation in adipose tissue, muscle-released IL-6 inhibition of TNF- $\alpha$ and the cholinergic anti-inflammatory pathway ${ }^{52}$.

The current study has important strengths and limitations. The major strength is the supervised nature of the study. However, all exercise sessions were supervised. Moreover, the study was randomized; hence, we can extrapolate adherence to the general population. In the other hand, the major limitations is only post-menopausal women enrolled in the study, so the value of this study only related to women in this age group, also small sample size in both groups may limit the possibility of generalization of the findings in the present study. Finally, within the limit of this study, aerobic exercise training is recommended for modulation of low grade systemic inflammation and quality of life among obese post-menopausal women. Further researches are needed to explore the impact of weight reduction on quality of life and other biochemical parameters among post-menopausal women.

\section{Conclusion}

The current study provides evidence that weight reduction program improves biochemical \& clinical parameters and quality of life among obese post-menopausal women. The strengths of this trial include its large sample size and randomized controlled design. There is no doubt that further studies are necessary to understand cellular and molecular mechanisms involved in relationships among weight reduction and changes of overall subscales of SF36.

\section{Acknowledgment}

This project was funded by the Deanship of Scientific Research (DSR) at King Abdulaziz University, Jeddah, 
under grant no. (G-4-142-1439). The authors, therefore, acknowledge with thanks DSR for technical and financial support.

\section{Conflict of interest}

None declared.

\section{References}

1. Jones G, Sutton A. Quality of life in obese post-menopausal women. Menopause Int 2008;14(1):26-32.

2. Flegal K, Carroll M, Ogden C, Curtin L. Prevalence and trends in obesity among US adults, 1999-2008. JAMA 2010;303(3):235-241.

3. Fuller N, Lau N, Denyer G, Simpson A, Gerofi J, Wu M, Holmes A, Markovic T, Kang J, Caterson I. A 12week, randomised, controlled trial to examine the acceptability of the Korean diet and its effectiveness on weight and metabolic parameters in an Australian overweight and obese population. Obesity Research \& Clinical Practice 2012;6(1): e71-e83.

4. World Health Organisation .Obesity and overweight. Geneva, Switzerland: World Health Organisation, 2011.

5. World Health Organisation (2011): Global strategy on diet, physical activity and health. Geneva, Switzerland: World Health Organisation.

6. Kruger J, Bowles HR, Jones DA, Ainsworth BE, Kohl HW. Health related quality of life, BMI and physical activity among US adults ( $\mathrm{N}=18$ years): National physical activity and weight loss survey, 2002. International Journal of Obesity 2003;31: 321-327.

7. McInnes R, Gray C. Obese Women and Quality of Life. Obesity 2013;15:585-595.

8. Dennerstein L, Lehert P, Guthrie J. The effects of the menopausal transition and biopsychossocial factors on well-being. Arch. Women Ment Health 2002;5:15-22.

9. De Lorenzi DR, Baracat EC, Saciloto B, Padilha JI. Fatores associados a 'qualidade de vida apo's menopausa. Rev Asso. Med Bras 2006; 52:312-317.

10. Hess R, Colvin A, Avis NE, Bromberger JT, Schocken M, Johnston JM, Matthews KA. The impact of hormone therapy on health-related quality of life: longitudinal results from the Study of Women's Health Across the Nation. Menopause 2007;15:422-428.

11. Moriyama CK, Oneda B, Bernardo FR, Cardoso Junior CG, Forjaz CL, Abrahao SB,Mion D, Fonseca AM, Tinucci T. Arandomized, placebo-controlled trial of the effects of physical exercises and estrogen therapy on health-related quality of life in post-menopausal women. Menopause 2008;15:613-618.

12. Salmon P. Effects of physical exercise on anxiety, depression, and sensitivity to stress: a unifying theory. Clinical Psychology Review 2001; 21: 33-61 PubMed .

13. Larson EB. Prospects for delaying the rising tide of worldwide, late-life dementias. International Psychogeriatrics. 2010; 22:1196-1202.

14. Vogt T, Schneider S, Bruumer V, Struder H K. Frontal EEG asymmetry: The effects of sustained walking in the elderly. Neuroscience Letters. 2010; 485:134-137.

15. Benloucif S, Orbeta L, Ortiz R, Janssen I, Finkel SI, Bleiberg J. Morning or evening activity improves neuropsychological performance and subjective sleep quality in older adults. Sleep 2004;15: 1542-1551. PubMed .

16. van Gelder BM, Tijhuis MA, Kalmijn S, Giampaoli S, Nissinen A, Kromhout D. Physical activity in relation to cognitive decline in elderly men: The FINE study. Neurology 2004; 28: 2316-2321. PubMed .

17. Oldenburg S, Boll D, Nicolaije K, Vos M, Pijnenborg J, Coebergh J, Beijer S, van de Poll-Franse L, Ezendam $\mathrm{N}$. The relationship of body mass index with quality of life among endometrial cancer survivors: A study from the population-based PROFILES registry. Gynecologic Oncology 2013;129: 216-221.

18. Deibert P, Konig D, Vitolins MZ. Effect of a weight loss intervention on anthropometric measures and metabolic risk factors in pre- versus post-menopausal women. J Nutr 2007; 6:31.

19. Hagey AR, Warren MP. Role of exercise and nutrition in menopause. Clin Obstet Gynecol 2008;51:627-41.

20. Woodward MJ, Lu CW, Levandowski R, Kostis J, Bachmann G. The exercise prescription for enhancing overall health of midlife and older women. Maturitas 2015 Sep;82(1):65-71.

21. Xu X, Ji W, Lv X, Zhu Y, Zhao J, Miao L. Impact of physical activity on health-related quality of life in osteoporotic and osteopenic post-menopausal women: A systematic review. International Journal of Nursing Sciences; 2:2 0 4-2 1 7, 2015.

22. Orsatti FL, Nahas EAP, Maesta N, Nahas-Neto J, Burini RC. Plasma hormones, muscle mass and strength in resistance-trained post-menopausal women. Maturitas 2008;59:394-404.

23. Maesta' N, Nahas EAP, Nahas-Neto J, Orsatti FL, Fernandes CE, Traiman P, Burini RC. Effects of soy protein and resistance exercise on body composition 
and blood lipids in post-menopausal women. Maturitas 2007;56:350-358.

24. Teomana N, Özcan A, Acar B. The effect of exercise on physical fitness and quality of life in post-menopausal women. Maturitas, $47: 71-77,2004$.

25. Kanemaru A, Arahata K, Ohta T, Katoh T, Tobimatsu H, Horiuchi T. The efficacy of home-based muscle training for the elderly osteoporotic women: the effects of daily muscle training on quality of life (QoL). Arch Gerontol Geriatr, 51(2):169-72,2010.

26. de Souza Santos CA, Dantas EE, Moreira MH. Correlation of physical aptitude; functional capacity, corporal balance and quality of life (QoL) among elderly women submitted to a post-menopausal physical activities program. Arch Gerontol Geriatr, 53(3):344-9,2011.

27. Berin E, Hammar ML, Lindblom H, Lindh-Åstrand L, Spetz Holm AC. Resistance training for hot flushes in post-menopausal women: Randomized controlled trial protocol. Maturitas. 2016 Mar;85:96-103.

28. Küçükçakır N, Altan L, Korkmaz N. Effects of Pilates exercises on pain, functional status and quality of life in women with post-menopausal osteoporosis. J Bodyw Mov Ther. 2013 Apr;17(2):204-11.

29. Sattar M, Esfarjani F, Nezakatalhosseini M. The effect of aquatic-resistance training on quality of life in post-menopausal women. Procedia - Social and Behavioral Sciences 70 ( 2013 ) 1732 - 1739.

30. Bonganha V, Modeneze DM, Madruga VA, Vilarta R. Effects of resistance training (RT) on body composition, muscle strength and quality of life (QoL) in post-menopausal life. Arch Gerontol Geriatr. 2012 MarApr;54(2):361-5.

31. Imayama I, Alfano CM, Cadmus Bertram LA, Wang C, Xiao L, Duggan C, Campbell KL, Foster-Schubert KE, McTiernan A. Effects of 12-month exercise on health-related quality of life: a randomized controlled trial. Prev Med 2011; 52(5):344-51.

32. Paluska SA, Schwenk TL. Physical activity and mental health: current concepts. Sports Med 2000; 29:167- 80 PubMed .

33. van Praag H, Christie BR, Sejnowski TJ, Gage FH. Running enhances neurogenesis, learning, and longterm potentiation in mice. Proc Natl Acad Sci U S A 1999; 96:13427-31.

34. Barde YA. Neurotrophins: a family of proteins supporting the survival of neurons. Prog Clin Biol Res 1994; 390:45-56 PubMed .

35. Lu B, Chow A. Neurotrophins and hippocampal synaptic transmission and plasticity. J Neurosci Res 1999; 58:76-87 PubMed .

36. Black JE, Isaacs KR, Anderson BJ, Alcantara AA, Greenough WT. Learning causes synaptogenesis, whereas motor activity causes angiogenesis, in cerebellar cortex of adult rats. Proc Natl Acad Sci, USA 1990; 87:5568-72.

37. Isaacs KR, Anderson BJ, Alcantara AA, Black JE, Greenough WT. Exercise and the brain: angiogenesis in the adult rat cerebellum after vigorous physical activity and motor skill learning. J Cereb Blood Flow Metab 1992; 12:110-9.

38. Greist JH, Klein MH, Eischens RJ, Faris J, Gurman AS, Morgan WE. Running as treatment for depression. Compr Psychiatry 1979; 20:41 -54 PubMed.

39. Dekker M, Lee S, Hudson R, Kilpatrick K, Graham T, Ross R. An exercise intervention without weight loss decreases circulating interleukin-6 in lean and obese men with and without type 2 diabetes mellitus. Metabolism 2007; 56(3):332-8. PubMed

40. You T, Berman D, Ryan A, Nicklas B. Effects of hypocaloric diet and exercise training on inflammation and adipocyte lipolysis in obese post-menopausal women. $J$ Clin Endocrinol Metab 2004; 89(4):1739-46.

41. Larsen A, Aukrust P, Aarsland T, Dickstein K. Effect of aerobic exercise training on plasma levels of tumor necrosis factor alpha in patients with heart failure. $A m \mathrm{~J}$ Cardiol 2001; 88(7):805-8. PubMed

42. Giannopoulou I, Fernhall B, Carhart R, Weinstock R, Baynard T, Figueroa A, Kanaley J. Effects of diet and/or exercise on the adipocytokine and inflammatory cytokine levels of post-menopausal women with type 2 diabetes. Metabolism 2005; 54:866-75 PubMed.

43. Troseid M, Lappegard KT, Mollnes T, Arnesen H, Seljeflot I. The effect of exercise on serum levels of interleukin-18 and components of the metabolic syndrome. Metab Syndr Relat Disord 2009;7(6):579-84.

44. Rosety-Rodriguez M, Camacho A, Rosety I, Fornieles G, Rosety MA, Diaz AJ, Rosety M, Ordonez FJ. Resistance circuit training reduced inflammatory cytokines in a cohort of male adults with Down syndrome. Med Sci Monit 2013; 19:949-53 PubMed .

45. Brooks N, Layne J, Gordon P, Roubenoff R, Nelson M, Castaneda-Sceppa C. Strength training improves muscle quality and insulin sensitivity in Hispanic older adults with type 2 diabetes. Int J Med Sci 2007; 4:19-27 PubMed . 46. Rosa N, Lira F, Oyama L, Zanchi N, Yamashita A, Batista M, Oller do Nascimento C, Seelaender M. Exhaustive exercise causes an anti-inflammatory effect in skeletal 
muscle and a pro-inflammatory effect in adipose tissue in rats, Eur J Appl Physiol 2009; 106: 697-704. PubMed

47. Rall L, Roubenoff R, Cannon J, Abad L, Dinarello

C, Meydani S. Effects of progressive resistance training on immune response in aging and chronic inflammation. Med Sci Sports Exerc 1996; 28:1356-65.

48. Rodrigo C, Celso R, Carvalho C. Impact of Resistance Training in Chronic Obstructive Pulmonary Disease Patients during Periods of Acute Exacerbation. Archives of Physical Medicine and Rehabilitation 2014; 95(9):1638-1645.

49. Nikseresht M, Agha-Alinejad H, Azarbayjani MA, Ebrahim K. Effects of nonlinear resistance and aerobic interval training on cytokines and insulin resistance in sedentary men who are obese. J Strength Cond Res 2014; 28(9):2560-8. PubMed

50. Kohut M, McCann D, Russell D, Konopka D, Cunnick J, Franke W, Castillo M, Reighard A, Vanderah E. Aerobic exercise, but not flexibility/ resistance exercise, reduces serum IL -18, CRP and IL-6 independent of beta-blockers, BMI and psychosocial factors in older adults. Brain Behav Immun 2006; 20(3):201-9.

51. Scheele C, Nielsen S, Pedersen B. ROS and myokines promote muscle adaptation to exercise. Trends Endocrinol Metab 2009; 20:95-9. PubMed

52. Woods J, Vieira V, Keylock K. Exercise, inflammation, and innate immunity. Neurol Clin 2006; 24(3):585-99. PubMed 